\title{
THEORIES AND COGNITIVE MODELS OF POST-NONCLASSICAL LEARNING IN NATURAL SCIENCE EDUCATION
}

\author{
TEORIAS E MODELOS COGNITIVOS DE APRENDIZAGEM PÓS-NÃO CLÁSSICA \\ NA EDUCAÇÃO EM CIÊNCIAS NATURAIS
}

\author{
TEORÍAS Y MODELOS COGNITIVOS DEL APRENDIZAJE POST-NO CLÁSICO EN \\ LA EDUCACIÓN EN CIENCIAS NATURALES
}

\author{
Suriya Irekovna GILMANSHINA ${ }^{1}$ \\ Lyudmila Vladimirovna MOISEEVA ${ }^{2}$ \\ Inna Nikolaevna PUSHKAREVA ${ }^{3}$ \\ Sergey Borisov IGNATOV ${ }^{4}$ \\ Iskander Rafailevich GILMANSHIN ${ }^{5}$
}

ABSTRACT: The cognitive models formed in post-nonclassical science-the theory of systems, the theory of self-organization and management, which were developed in natural science, are now widely used in social and humanitarian research. However, they have not yet been properly reflected in the content of natural science education of future employees of these fields graduates of social, humanitarian and pedagogical departments of higher education institutions. The purpose of this study is the theoretical and methodological justification, development and testing of a set of methodological tools for adapting cognitive models of post-non-classical science in the content of natural science education of students of social and humanitarian fields of higher education. Methodology and methods. The methodological basis of the research is based on the ideas of the system-synergetic approach, works on the philosophy and methodology of education, fundamental positions and basic principles of modern didactics. The theoretical basis is the works of domestic and foreign scientists on the development of the content of education, educational technologies and the organization of the educational process at the University. Was used modeling and forecasting, analysis and synthesis, observation, questioning, testing, experimental work. The theoretical and methodological justification of the need to adapt cognitive models of post-non-classical science in the content of natural science education of the Humanities is given, and the principles are defined. The complex has a linearconcentric structure and includes a basic training course, a system of elective training courses and interdisciplinary modules, technologies and teaching methods that support it. During testing

\footnotetext{
${ }^{1}$ University of Kazan, Kazan - Russia. Doctor of Sciences, Professor, Head of Department (Chemical Education) Alexander Butlerov Institute of Chemistry. ORCID: https://orcid.org/0000-0003-0302-000X. E-mail: gilmanshina@yandex.ru

${ }^{2}$ Ural state pedagogical University, Yekaterinburg - Russia. Doctor of Sciences, Professor, Faculty of natural science, physical culture and tourism, Department of theory and methods of physical culture and sports. ORCID: https://orcid.org/0000-0001-8358-6235. E-mail: moiseeva.lv@uspu.me

${ }^{3}$ Ural state pedagogical University, Yekaterinburg - Russia. Faculty of natural science, physical culture and tourism, Department of theory and methods of physical culture and sports. ORCID: https://orcid.org/0000-00025309-4309. E-mail: inna.ru.80@mail.ru

4 Tyumen Industrial University, Tyumen - Russia. Department of Humanities and technologies. ORCID: https://orcid.org/0000-0003-0302-000X. E-mail: ignatoff.se2017@yandex.ru

${ }^{5}$ National Research Technical University named after A. N. Tupolev, Kazan - Russia. PhD., Associate professor, Electrical equipment department, Institute for Automation and Electronic Instrumentation. ORCID: https://orcid.org/0000-0001-9766-0598. E-mail: is-er@yandex.ru
} 
of the complex was performed: ability to operate basic concepts of post-nonclassical science and apply them to describe the behavior of social and natural systems of different complexity, the volume of natural Sciences students' knowledge, proficiency with the operation of their transfer to other subject areas.

KEYWORDS: Natural science education. Cognitive model. Post-nonclassical science. Complex of methodological tools.

RESUMO: Os modelos cognitivos formados na ciência pós-não clássica - a teoria dos sistemas, a teoria da auto-organização e gestão, que foram desenvolvidos nas ciências naturais, são agora amplamente usados na pesquisa social e humanitária. No entanto, eles ainda não foram devidamente refletidos no conteúdo da educação em ciências naturais dos futuros funcionários dessas áreas - graduados de departamentos sociais, humanitários e pedagógicos de instituições de ensino superior. O objetivo deste estudo é a justificação teórica e metodológica, desenvolvimento e teste de um conjunto de ferramentas metodológicas para a adaptação de modelos cognitivos de ciências pós-não clássicas no conteúdo do ensino de ciências naturais de alunos das áreas sociais e humanitárias do ensino superior. A base metodológica da pesquisa é baseada nas ideias da abordagem sinergética do sistema, trabalhos sobre a filosofia e metodologia da educação, posições fundamentais e princípios básicos da didática moderna. A base teórica são os trabalhos de cientistas nacionais e estrangeiros sobre o desenvolvimento do conteúdo da educação, tecnologias educacionais e a organização do processo educacional na Universidade. Ao longo do estudo foram usadas modelagem e previsão, análise e síntese, observação, questionamento, teste, trabalho experimental. É apresentada a justificação teórica e metodológica da necessidade de adaptar os modelos cognitivos das ciências pós-não clássicas ao conteúdo do ensino das ciências naturais das Humanidades e definidos os princípios. O complexo tem uma estrutura linearconcêntrica e inclui um curso básico de formação, um sistema de cursos eletivos de formação e módulos interdisciplinares, tecnologias e métodos de ensino que o apoiam. Durante os testes se observou capacidade de operar conceitos básicos de ciências pós-não clássicas e aplicá-los para descrever o comportamento de sistemas sociais e naturais de complexidade diferente, o volume de conhecimento dos alunos de ciências naturais, proficiência com a operação de sua transferência a outras áreas temáticas.

PALAVRAS-CHAVE: Ensino de ciências naturais. Modelo cognitivo. Ciências pós-não clássicas. Complexo de ferramentas metodológicas.

RESUMEN: Los modelos cognitivos formados en la ciencia posno clásica: la teoría de sistemas, la autoorganización y la teoría de la gestión, que se desarrollaron en las ciencias naturales, ahora se utilizan ampliamente en la investigación social y humanitaria. Sin embargo, aún no se han reflejado adecuadamente en el contenido de la educación en ciencias naturales de los futuros empleados en estas áreas: graduados de los departamentos sociales, humanitarios y pedagógicos de las instituciones de educación superior. El objetivo de este estudio es la justificación teórica y metodológica, el desarrollo y la puesta a prueba de un conjunto de herramientas metodológicas para la adaptación de modelos cognitivos poscientíficos no clásicos en la enseñanza de las ciencias naturales de estudiantes de las áreas sociales y humanitarias de educación superior. La base metodológica de la investigación se basa en las ideas del enfoque sinérgico del sistema, trabaja sobre la filosofía y metodología de la educación, posiciones fundamentales y principios básicos de la didáctica moderna. La base 
teórica es el trabajo de cientificos nacionales y extranjeros sobre el desarrollo de contenidos educativos, tecnologías educativas y la organización del proceso educativo en la Universidad. A lo largo del estudio se utilizaron modelos y predicción, análisis y síntesis, observación, cuestionamiento, prueba, trabajo experimental. Se presenta la justificación teórica y metodológica de la necesidad de adaptar los modelos cognitivos de las ciencias posno clásicas a los contenidos didácticos de las ciencias naturales de las Humanidades y se definen los principios. El complejo tiene una estructura lineal-concéntrica e incluye un curso de formación básica, un sistema de cursos de formación electivos y módulos interdisciplinarios, tecnologías y métodos de enseñanza que lo soportan. Durante las pruebas, se observó la capacidad de operar conceptos básicos de las ciencias posno clásicas y aplicarlos para describir el comportamiento de los sistemas sociales y naturales de diferente complejidad, el volumen de conocimiento de los estudiantes de ciencias naturales, la competencia con la operación de su traslado a otras áreas temáticas.

PALABRAS CLAVE: Educación en ciencias naturales. Modelo cognitivo. Ciencia post-no clásica. Complejo de herramientas metodológicas.

\section{Introduction}

In recent decades, the methods of post-non-classical science are increasingly used in such humanitarian fields as building models of social interactions and behavior of social groups, historical, political, cultural and economic processes, the development of competitive relations, elections, social games in the social network, forecasting the future, and others. In modern conditions of digital reality (GILMANSHINA; GILMANSHIN; BENDJUKEVICH, 2019) and the need for sustainable development (GILMANSHINA; GILMANSHIN; DYATLOVA, 2019) there is an Increasing demand for specialists with non-linear thinking (GILMANSHINA; SAGITOVA; GILMANSHIN, 2018), who can make non-standard decisions using the methodology of post-non-classical science and its potential to overcome emerging problems.

However, it is impossible to simply transfer (reduce) theories, models, approaches, and achievements of science to the content of education. They must be adapted to the age characteristics of students, the conditions, and specifics of their training. The development of methodological tools for their adaptation in modern conditions not only does not lose its significance but becomes even more relevant. In this regard, it is necessary to rethink the structure and content of natural science education for humanitarians, its role in their professional training and its place in the curricula of social and humanitarian departments of higher education institutions.

Issues of improving the quality of natural science education of different categories of students are constantly in the field of view specialists (MAINZER, 2004; ABD-EL-KHALICK, 2012; ALLCHIN, 2011; HANUSCIN; LEE; AKERSON, 2011). 
Researchers working in the field of methods of science education in the Humanities, offered different options to overcome these problems. However, despite the efforts made and some success of researchers, this course was not productive enough.

Even in the nineties of the last century, the question of the possibility of adapting cognitive models of post-non-classical science in its content begins to be discussed.

Simultaneously, the didactic aspects of the implementation of these models in the content of natural science education of humanitarians and the issues of its specific construction are discussed. V. G. Budanov (2009), one of the first developers of the CSE course and initiators of its introduction into the educational process, believed that its study should begin with the ideas of post-non-classical science. V. G. Vinenko (1999), based on the ideas of the systemsynergetic approach, developed a didactic model of the content of continuous natural science education of teachers and a system of natural science courses that implement it. Gapontseva, Fedorov and Gapontsev (2004), considering an integrative approach to the content of science education, revealed the influence of evolutionary science on its structure and content, the possibility of applying the methodology of synergetics, the principle of symmetry and fractality to the formation of its contents. S. E. Starostina (2012) developed a model for science education in the Humanities considering integration processes in science and areas of training graduates.

However, unified approaches to modeling and designing natural science education in the Humanities have not yet been developed. Questions of its content, training technologies, and position in the structure of professional training of graduates require further research.

\section{Methods}

Every year, 150 people (four experimental groups and one control group) participated in the experimental search work on the implementation of the complex. Students of the control group (CG) studied the course "KSE". Students of experimental groups (EG) mastered the complex developed by us. The total number of classroom hours remained unchanged ( 54 hours) but could be redistributed between different forms of organization of the educational process. Students of the EG1 group studied the SNCM course, and the EG2 and EG3 groups also studied elective support courses. Practical classes in the EG4 group were held in a computer class.

Three levels of student achievement were justified: low, medium, and high. Success was assessed based on the results of performing the level tasks presented. We used both standard tasks and non-standard tasks that require independent search for additional knowledge. Tasks that correspond to a high level of achievement were creative in nature and were associated with 
identifying students' skills to design, model and predict the development of systems, build an algorithm for their research. Quantitative assessment of the subjects' achievements was carried out according to the methods used in psychological and pedagogical research. Along with quantitative methods, qualitative methods were also used: observation, questionnaires, interviews, analysis of essays, portfolios, and individual projects. Both percentages and "sample averages" (statistical weights) of student distributions by level (G) were used. The cumulative effect in the measured features was estimated by increment of statistical weights $(\Delta \mathrm{G})$. To assess the reliability of the results obtained, the two-sided Pearson $\chi 2$-test was used. Significance was assessed at the level of 0,05. Diagnostic tests were performed at three reference points-the beginning, middle and end of the semester. Was diagnosed following achievement of students: the volume of natural scientific knowledge (1), the ability to transfer them to other subject areas (2), understanding of theories of systems, self-organization and management (3), the ability to operate on their conceptual and categorical apparatus in the different fields of knowledge (4), the ability to use them to qualitative descriptions of behavior of different socioecosystem (5). Along with these recorded changes in the socio-personal qualities of students.

\section{Results and discussion}

As part of the research work, we developed a didactic model of the content of natural science education for students of social and humanitarian training profiles and a methodological complex that implements it. Conceptual approaches to its modeling are considered in our work (IGNATOVA; IGNATOV, 2017).

The complex has a linear-concentric structure and consists of content and process blocks. The content block includes a nuclear course, a set of elective courses supporting it, and interdisciplinary modules. In their content, elements of the theory of systems, self-organization and management are presented in an adapted form that is accessible to the humanist. The process block includes a set of technologies and methods for active learning (case study, web quest, individual and collective projects etc.), a Bank of professionally-oriented search and research tasks, and control tasks.

Depending on the conditions (the layout of the curriculum, the number of hours allocated for studying the course, the set of elective courses, the possibility of using a computer workshop etc.), the elements of the content block were used in universities of the Tyumen and 
Sverdlovsk regions collectively or separately, as well as in universities of the Republic of Tatarstan.

The core of the complex is our author's training course "Modern scientific picture of the world (SNCM)" (IGNATOV; IGNATOVA, 2010). The Central idea of its modeling is the integration of diverse knowledge, implemented at the empirical, theoretical and methodological levels. Convergence, complementarity, transdisciplinary and system-synergetic approaches were used as tools for its implementation.

Content development, selection and structuring of teaching material was carried out according to the following criteria of its importance in the educational process: fundamentalization education, the conformity of its content to the level of development of science; - provision of transdisciplinarity knowledge in natural Sciences, the implementation of horizontal and vertical linkages course from other academic disciplines; - the possibility of using the deductive method of learning is more acceptable in high school compared to inductive, offered in a traditional course "concepts of modern science»; - formation of students' system-synergetic picture of the world, non-linear thinking and ideas about universal evolutionism; - creation of conditions for understanding and using cognitive models of postnonclassical science in the professional sphere and acquisition of competencies necessary for solving professionally significant tasks; - expansion and harmonization of the cognitive sphere of students based on the integration of natural science and Humanities knowledge; - access to the humanitarian problems of our time and understanding the need for a dialogue of cultures in their solution; - development of the student's personality and activation of the educational function of training.

The course has a block-modular structure and consists of invariant and variable (applied) parts. The invariant part remains unchanged for all students. The content of the variable part varies depending on the training profile.

The core of the invariant part is the module "post-nonclassical science and its main ideas", which introduces students to the dynamics of scientific knowledge, fundamental concepts and cognitive models of post-nonclassical science, its conceptual and categorical apparatus and research procedures, builds a system-synergetic picture of the world and reveals the ideas of universal evolutionism. The concepts and models presented in this module are logically continued in the content of the subsequent modules of the course, which demonstrate the possibility of their application to the construction of cosmological, physical, chemical, geological, biological, anthropological, socio-cultural, economic and environmental images of the world. The content of the variable part reveals the possibilities of using the methodology of 
post-nonclassical science in the upcoming research work of senior students and their future professional activities. Those who wish to deepen their knowledge in the use of concepts, methods and cognitive models of post-nonclassical science were offered a choice of elective support courses and electives developed by us: "Concepts of post-nonclassical science in Humanities research", "socioecosystems and methods of their research", "Synergetics and socio-cultural dynamics", "Synergetics and Economics". This allowed students not only to meet their cognitive needs and interests, but also to choose ways to master the educational material.

As an example, we give the structure and content of the course "Concepts of postnonclassical science in Humanities research".

Cycle 1. The Genesis of scientific rationality. Topics: Unity of the world and ways to understand it. Evolution of the scientific method of research: from natural philosophy to postnon-classical ideas. Post-nonclassical science. Concepts of consistency, self-organization, and management. System-synergetic picture of the world and universal evolutionism.

Cycle 2. Using cognitive models of post-non-classical science in Humanities research. Topics: Synergetic interpretation of socio-cultural processes. Methodology of post-nonclassical science in social and humanitarian research: socio-ecosystems, Economics, cultural studies, pedagogy. In a concentrated form, the content of elective courses became the basis for the construction of interdisciplinary mobile modules, which were used as generalizations in the study of individual topics of the disciplines of the socio-humanitarian and professional cycles of the curriculum.

The use of training technologies proposed in the procedural block of the complex allowed us to shift the emphasis of the educational process to the acquisition of competencies and experience in the study of professionally significant tasks using the ideas, methods and models of post-nonclassical science. To do this, in the framework of seminars and laboratory work was provided by the case studies, quests, and projects: "the world through the prism of synergetics", "self-organization in nature", "self-organization and organization in social systems", "Exponential growth", "Limits to growth", "Quality of life", "Ethnogenesis and civilizational faults", "Modeling socioecosystem", "Modeling social processes and projections of future", "Economically sustainable" and others.

When developing their content, the works of S.P. Kapitsa, G. G. Malinetsky, D. H. and D. L. Meadows, N. N. Moiseev, Yu. M. Plotinsky, and J. Forrester were used (MEADOWS; RANDERS; MEADOWS, 2007; VOROSHCHUK; PEGOVA, 2003). Considerable emphasis was placed on the advanced independent work of students. Since first-year students do not have sufficient knowledge of mathematical methods, modeling the development of systems and their 
development processes was of a qualitative nature. But it performed an important heuristic function in the development of subsequent disciplines of the professional cycle.

Increments of statistical weights of the diagnosed indicators that characterize students ' achievements in the course of ODA are shown in figure 1. The numbers of the diagnosed indicators $(1,2,3,4,5)$ are shown horizontally, and the increments of their statistical weights $(\Delta \mathrm{G})$ in the groups of subjects by the end of the semester are shown vertically.

Figure 1 - The histogram of the increment of statistical weights of diagnosed parameters

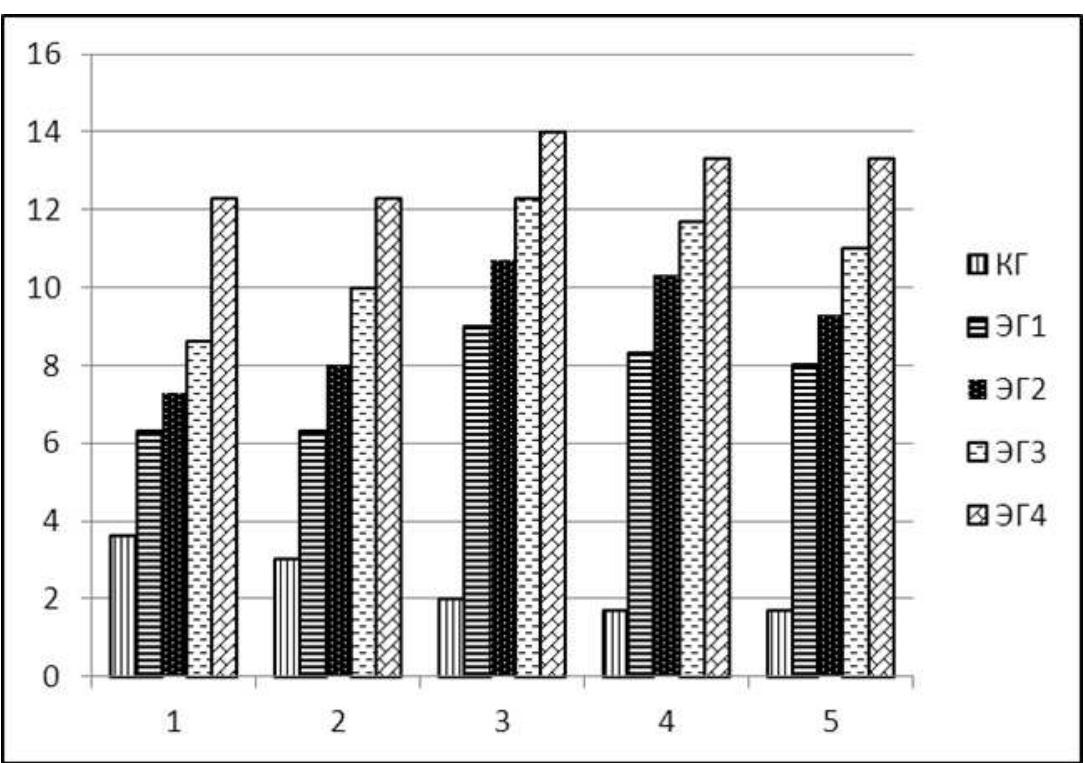

Source: Devised by the authors

\section{Summary}

Increment of statistical weights of indicators is observed in all groups of subjects. But the results obtained in different groups have significant differences. In the control group, the diagnosed indicators grow by the end of the semester but remain low. The situation is much better in the EG1 group, whose students studied the SNCM course. In comparison with students of $\mathrm{KG}$, significantly increasing the volume of natural scientific knowledge grows, the level of conceptual and categorical apparatus of science, form the skills of using cognitive models of post-nonclassical science for qualitative descriptions of processes in social and natural environment. The success of students, in our opinion, is directly related to the content and structuring of the course content, which combines the concentricity and linearity of the presentation of educational material. The sequence of its study built in the course helps students to comprehend the deductive method of mastering educational material, leads them to understand the idea of universal evolutionism, contributes to the development of non-linear 
thinking, the formation of such universal educational actions as the operation of transferring acquired knowledge to different subject areas, which is important for building a complete picture of the world. Students of the experimental groups EG2 and EG3 have an even more significant increase in the diagnosed indicators. This is largely helped by the parallel study of supportive, professionally oriented elective courses. The highest indicators are in the EG4 group. This is where working in the computer lab affects. It contributes to a more dynamic accumulation of knowledge, development in the virtual space of skills for modeling socionatural systems and forecasting their development, which can be used in future professional activities.

According to expert assessments of teachers of other training courses, the use of interdisciplinary modules as generalizations in the study of individual topics or sections of disciplines in the social, humanitarian and professional cycles helps to develop them more deeply. And what is important, the inclusion of the proposed methodological complex in the educational process increases the educational potential of the educational content. Students of experimental groups are more likely to show the ability to work in a team, create a collective intellectual product, and be responsible for the results of not only their own work, but also the entire team.

We have constructed a graphical profile of changes in the diagnosed indicators corresponding to the histogram of increment of statistical weights (Fig. 2). It clearly shows that the use of the proposed complex not only expands the cognitive field of students, but also increases its symmetry in the direction of KG - EG1 - EG2 - EG3 - EG4. This indicates the synchronicity of introduced innovations and changes in the achievements of students, indicates the harmonization of their cognitive sphere. 
Figure 2 - Graphical profile of the increment of the diagnosed parameters

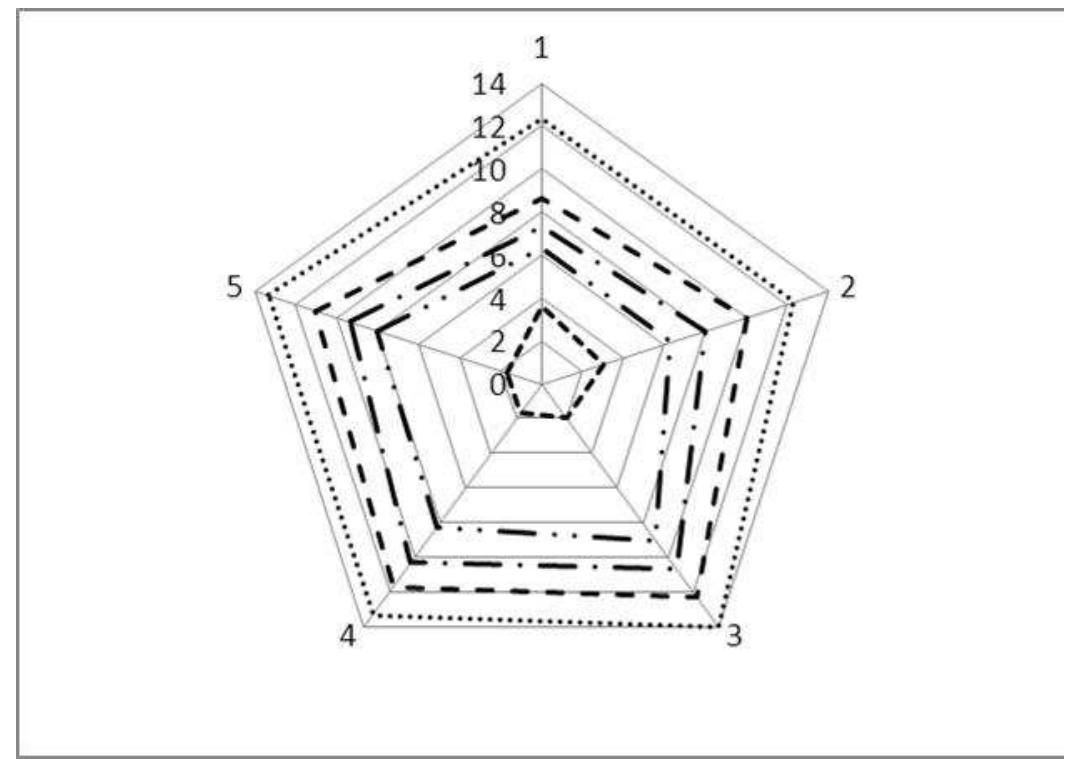

Source: Devised by the authors

The results obtained in the course of the ERP, with a 95\% probability, indicate that the positive changes observed in the experimental groups are associated with the introduced innovations. This conclusion is confirmed by statistical processing of the results of diagnostic studies. The value of $\chi^{2}$ for samples EG1, EG2, EG3 and EG4 for the diagnosed indicators varies in the range of 18.63-26.13, which is significantly higher than the $\chi^{2}=5.99$. While for the CG group, the differences are insignificant $\left(\chi^{2}<5.99\right)$ or weak $\left(\chi^{2} \approx 8.03-8.13\right)$.

\section{Conclusion}

The article presents a theoretical and methodological justification of the need to adapt the theories and cognitive models of post-non-classical science in the natural science education of the Humanities. A methodological complex that implements this idea is proposed and tested.

It can be argued that the use in the educational process of the complex built in the proposed way: - fundamentalizes education, creates favorable conditions for understanding the idea of universal evolutionism, - helps students build a holistic system-synergetic picture of the world; - significantly increases the volume of natural science knowledge, contributes to their deepening, harmonizes the cognitive sphere of students; - leads to an understanding of the importance of natural Sciences in the social and humanitarian sphere; - promotes the development of skills to use them in professional activities; - develops universal learning activities; - activates the educational functions of the educational process, expands its 
capabilities in the development of the student's personality. This gives reason to believe that the proposed complex can be used as one of the options for modernizing the natural science education of the Humanities.

ACKNOWLEDGEMENTS: The work is performed according to the Russian Government Program of Competitive Growth of Kazan Federal University.

\section{REFERENCES}

ABD-EL-KHALICK, F. Examining the sources for our understandings about science: Enduring conflations and critical issues in research on nature of science in science education. International Journal of Science Education, v. 34, n. 3, p. 353-374, 2012.

ALLCHIN, D. Evaluating knowledge of the nature of (whole) science. Science Education, v. 95, n. 3, p. 518-542, 2011.

BUDANOV, V. G. Methodology of synergetic in post-nonclassical science and education. Moscow: Knizhny Dom, 2009. 240 p.

FORRESTER, J. World dynamics. Translated from English by A. Voroshchuk and S.Pegova. Moscow, 2003. 379 p.

GAPONTSEVA, M. G.; FEDOROV, V. A.; GAPONTSEV, V. L. Application of the ideology of synergetic to the formation of the content of continuous science education. Education and Science, v. 6, n. 30, p. 90-102, 2004.

GILMANSHINA, S. I.; GILMANSHIN, I. R.; BENDJUKEVICH, K. G. Digital learning technologies in the University education system. IOP Conference Series: Materials Science and Engineering, v. 570, n. 1, 2019. Available:

https://iopscience.iop.org/article/10.1088/1757-899X/570/1/012027. Access: 10 Jan. 2021.

GILMANSHINA, S. I.; SAGITOVA, R. N.; GILMANSHIN, I. R. Science Education: Development of Environmental Thinking. European Research Studies Journal, v. XXI, n. 3, p. 690-704, 2018.

GILMANSHINA, S.I.; GILMANSHIN, I. R.; DYATLOVA, E. V. Formation of competencies of the 21st century by means of project activities. IOP Conference Series: Materials Science and Engineering, v. 570, n. 1, 2019. Available: https://iopscience.iop.org/article/10.1088/1757-899X/570/1/012026. Access: 10 Jan. 2021.

HANUSCIN, D. L.; LEE, M. H.; AKERSON, V. L. Elementary teachers' pedagogical content knowledge for teaching the nature of science. Science Education, v. 95, n. 1, p. 145 $167,2011$.

IGNATOV, S. B.; IGNATOVA, V. A. Modern scientific model of the world. Tyumen: TyumSOGU, 2010. 240 p. 
IGNATOVA, V. A.; IGNATOV, S. B. Conceptual approaches to modeling the content of science education of students of social and humanitarian areas of training at the university. Bulletin of the Tyumen State University. Humanities, v. 3, n. 3, p. 222-232, 2017.

MAINZER, K. Thinking in Complexity. The Complex Dinamics of Matter, Mind and Mankind. Berlin: Springer-Vertag, 2004. 356 p.

MEADOWS, D.; RANDERS, J.; MEADOWS, D. Limits of growth. 30 years later. Translated from English. Moscow, 2007. 342 p.

STAROSTINA, S. E. Science education of students of humanitarian areas of training in the context of the integration of scientific knowledge. Chita: ChSPU, 2012. $472 \mathrm{p}$.

VINENKO, V. G. Building the content of the teacher's continuing education. Systemic synergetic approach. Saratov: Publishing house Sarat. University, 1999. 244 p.

\section{How to reference this article}

GILMANSHINA, S. I.; MOISEEVA, L. V.; PUSHKAREVA, I. N.; IGNATOV, S. B.; GILMANSHIN, I. R. Theories and cognitive models of post-nonclassical learning in natural science education. Revista on line de Política e Gestão Educacional, Araraquara, v. 25, n. esp. 6, p. 3525-3537, Dec. 2021. e-ISSN:1519-9029. DOI: https://doi.org/10.22633/rpge.v25iesp.6.16114

Submitted: $15 / 04 / 2021$

Required revisions: $28 / 08 / 2021$

Approved: 29/11/2021

Published: $30 / 12 / 2021$

Processing and publication by the Editora Ibero-Americana de Educação. Correction, formatting, standardization and translation.

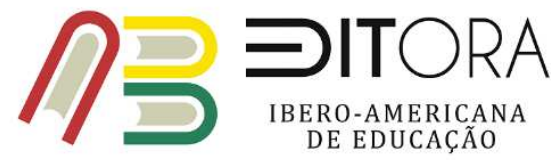

